\title{
The effect of portal and peripheral insulin delivery on carbohydrate and lipid metabolism in a miniature pig model of human IDDM
}

\author{
J.P.Canavan' ${ }^{1}$, P.A . Flecknell ${ }^{2}$, J.P.New ${ }^{1}$, K.G.M.M.A Iberti ${ }^{1}$, P.D.H ome ${ }^{1}$ \\ ${ }^{1}$ Human Diabetes and Metabolism Research Centre and Department of Medicine, University of Newcastle Upon Tyne, UK \\ ${ }^{2}$ Comparative Biology Centre, University of Newcastle Upon Tyne, UK
}

Summary A pig model of insulin-dependent diabetes was used to examine the importance of the portal-systemic insulin gradient for whole-body metabolic control. Six pigs had jugular vein, portal vein, and carotid artery cannulae implanted before being made diabetic (150 mg kg-1 streptozotocin). Each animal received 4 weeks of portal and 4 weeks of peripheral insulin delivery in random order. The blood glucose target range was 5-10 $\mathrm{mmol} \cdot \mathrm{l}^{-1}$, and serum fructosamine and fasting and postprandial blood glucose concentrations were not different between peripheral and portal insulin infusion. Insulin requirement was not different between the 4 week infusion periods, but fasting peripheral insulin levels after peripheral delivery $(124 \pm 16$ (mean $\left.\pm \mathrm{SEM}) \mathrm{pmol} \cdot \mathrm{l}^{-1}\right)$ were significantly higher $(\mathrm{p}<0.05)$ than in portally infused $\left(73.8 \pm 5.4 \mathrm{pmol} \cdot \mathrm{l}^{-1}\right)$ or pre-diabetic control animals $\left(68.4 \pm 3.6 \mathrm{pmol} \cdot \mathrm{l}^{-1}\right)$. Basal hepatic glucose output was also higher $(p<0.05)$ in peripherally $(4.2 \pm$ $0.4 \mathrm{mg} \cdot \mathrm{kg}^{-1} \cdot \mathrm{min}^{-1}$ ) than in portally infused animals $\left(2.9 \pm 0.4 \mathrm{mg} \cdot \mathrm{kg}^{-1} \cdot \mathrm{min}^{-1}\right)$ or controls $(3.0 \pm 0.3 \mathrm{mg}$. $\left.\mathrm{kg}^{-1} \cdot \min ^{-1}\right)$. Clamp glucose metabolic clearance rate was, however, not different between the peripheral and portal insulin delivery routes $(8.1 \pm 1.0 \mathrm{vs}$ $\left.9.0 \pm 0.7 \mathrm{ml} \cdot \mathrm{kg}^{-1} \cdot \mathrm{min}^{-1}\right)$, although both were significantly lower $(p<0.05)$ than that measured in prediabetic control animals $\left(11.7 \pm 1.0 \mathrm{ml} \cdot \mathrm{kg}^{-1}\right.$. $\left.\min ^{-1}\right)$. Lipid profiles and subfractions were similar in all three groups. It is concluded that the portal route of delivery is superior to the peripheral in maintaining more appropriate insulin concentrations and control of hepatic glucose output, although in the absence of euglycaemia it is still associated with significant metabolic abnormalities. [Diabetologia (1997) 40: $1125-1134]$

Keywords Type 1 diabetic model, minipig, streptozotocin, portal vein, insulin, glucose clearance, hepatic glucose production, lipids.
The normal portal-peripheral insulin gradient is absent in patients with insulin-dependent diabetes mellitus (IDDM) managed on conventional insulin

Received: 25 February 1997 and in revised form: 23 May 1997

Corresponding author: Dr. J. P. Canavan, Human Diabetes and Metabolism Research Centre, The Medical School, The University of Newcastle Upon Tyne, Newcastle upon Tyne NE2 $4 \mathrm{HH}, \mathrm{UK}$

A bbreviations: IDDM, Insulin-dependent diabetes mellitus; IVGTT, intravenous glucose tolerance test; NEFA, non-esterified fatty acids; VLDL, very low density lipoproteins, LDL, low density lipoproteins; HDL, high density lipoproteins; MCR, metabolic clearance rate; HGO, hepatic glucose output; $\mathrm{SA}$, specific radioactivity. therapy. The effect of this on intermediary metabolism has been studied widely in man and animals. However, results have been conflicting and considerable uncertainty still exists regarding the importance of the gradient for the maintenance of overall metabolic homeostasis.

In animal models the metabolic importance of the portal-systemic gradient has been examined using a variety of techniques including direct cannulation combined with exogenous insulin infusion, islet and pancreatic transplantation, and diversion of pancreatic venous drainage [1-21]. In some studies control of hepatic glucose output or blood glucose concentrations was superior with the portal route of insulin delivery, $[3,8,15,16,18,20]$ while in others no 
advantage was found $[2,6,9,11,14,21]$. Indeed some acute experiments have shown that peripherally delivered insulin is more effective than the same dose delivered portally $[1,5]$. A number of investigations have supported the concept that only portal insulin delivery can sustain normal insulin responsiveness $[13,18,20]$. Others, however, have yielded contradictory findings $[2,4,7,11,14,17,19]$.

In humans the importance of maintaining the portal-peripheral insulin gradient has been investigated mainly by comparing intraperitoneal (i. p., where the gradient is largely re-established [22]) with subcutaneous (s. c.) insulin delivery [23-28]. Metabolic control after pancreas transplantation and in chronic liver disease, when the portal-systemic gradient is lost, has also been the subject of investigation [2940]. Intraperitoneal studies have yielded somewhat conflicting results, with either improved [23, 24, 26, $29]$ or unchanged $[25,27,28]$ insulin sensitivity. Similarly pancreas transplantation has been shown by many [30-32, 34-37], but not all groups [33, 38] to cause a deterioration in insulin responsiveness.

The contradictory results of animal investigations may largely reflect differences in the experimental protocols employed, such as whether the animals had normal or impaired glucose tolerance, whether their diabetes was surgically or chemically induced, and whether the studies were short or long term. The actual species employed will also have influenced the experimental outcome, not least in determining their relevance to man. In this respect the pig is superior to the more commonly employed rodent or dog models by virtue of its greater endocrine, nutritional and anatomical similarity to man.

It is clear that for the full therapeutic potential of advances in islet and pancreatic transplantation and artificial pancreas technology to be realised, any uncertainties concerning which site of insulin delivery is most metabolically efficacious should be resolved. The aims of the present study were to develop a miniature-pig model of human IDDM. The pig because of its aforementioned physiological homology to man provides an excellent model with which to examine the significance of the portal-systemic insulin gradient for various aspects of metabolic control. Using this carefully defined model the relative impact of longer-term portal-vein compared to peripheral-vein insulin delivery on blood glucose control, intermediary and lipid metabolism, and glucose turnover was examined.

\section{Materials and methods}

A nimals. Male Göttingen mini-pigs, specific pathogen-free, were purchased (Ellegaard, Dalmose, Denmark) at 12 weeks of age and housed under controlled conditions $\left(21^{\circ} \mathrm{C}\right.$ room temperature and a 12-h light cycle from 07.00 to 19.00 hours).
Feeding was programmed twice daily at exactly 10.00 and 16.00 hours and on each occasion consisted of $250 \mathrm{~g}$ of a standard mini-pig diet (SMPZN; SDS, Witham, Essex, UK). United Kingdom regulations and guidelines concerning the care and use of experimental animals were strictly followed.

Study design. At approximately 52 weeks of age and with a body weight of $35 \pm 4.0 \mathrm{~kg}$ (mean \pm SD) animals underwent surgery (see following) to implant chronically indwelling carotid artery, jugular vein and portal vein cannulae. From 2-6 weeks post-surgery a series of diagnostic and experimental protocols were performed to obtain baseline values for a range of haematological, endocrine and biochemical measures. Whole body insulin sensitivity and rates of glucose turnover were also determined in each animal at this time (see insulin sensitivity and glucose turnover determinations below). A total of six animals were then made diabetic (see introduction of diabetes below) and managed with s.c. injections of insulin up to the start of infusion studies (see following). Eight to 50 weeks following induction of diabetes each animal underwent 28 days of programmed insulin delivery via either the jugular vein (peripherally), or the portal vein, using portable infusion pumps (see intravenous insulin treatments below). The initial route was randomly determined and after each 28-day study a further period of s.c. treatment ensued, lasting at least 10 days, before initiation of a further 4 weeks of insulin infusion by the alternate route. During the last week of each 4week treatment interval the diagnostic and experimental protocols performed before diabetes was induced were repeated.

Insulin therapy, whether subcutaneous or venous, was adjusted with the aim of keeping whole blood glucose within the range of $5.0-10.0 \mathrm{mmol} \cdot \mathrm{l}^{-1}$ in each animal throughout the study. Prior to induction of diabetes and before and after each infusion study an intravenous glucose tolerance test (IVGTT, see following) was carried out to establish reference values in normal animals and ensure that the streptozotocin-treated animals remained $\mathrm{C}$-peptide negative, and therefore accurately modelled human IDDM throughout the study.

Surgery. Anaesthesia was induced in the minipigs after an overnight fast, by intramuscular injection of ketamine (10.0 mg $\cdot \mathrm{kg}^{-1}$; Ketalar, Parke Davis, Eastleigh, UK) and diazepam emulsion $\left(2.0 \mathrm{mg} \cdot \mathrm{kg}^{-1}\right.$; Diazemuls, Dumex, Aylesbury, UK) and was maintained by inhalation of $1-2 \%$ isoflurane (Abbot, Maidenhead, UK) in oxygen (6-8 litres $\cdot \mathrm{min}^{-1}$ ). Under anaesthesia, polyurethane catheters (16 G, $150 \mathrm{~mm}$; Secalon Universal Ohmeda, Swindon, UK) were inserted into the carotid artery and jugular and portal veins using established procedures [41]. Cefuroxime (Zinacef $250 \mathrm{mg}$, i.v.; Glaxo, Greenford, UK) was administered immediately before and for $48 \mathrm{~h}$ post-operatively. Post-surgery analgesia consisting of buprenorphine $\left(0.005 \mathrm{mg} \cdot \mathrm{kg}^{-1}\right.$, i.v.; Temgesic, Rekitt \& Colman, Hull, UK) and Flunixin $\left(2 \mathrm{mg} \cdot \mathrm{kg}^{-1}\right.$, i.v.; Finadyne, Schering-Plough Animal Health, Welwyn Garden City, UK) was provided. Catheters were kept patent by daily flushing with $0.15 \mathrm{~mol} \cdot \mathrm{l}^{-1} \mathrm{NaCl}$ in water and were left filled with heparin (Leo, Aylesbury, UK) diluted to $1000 \mathrm{U} \cdot \mathrm{ml}^{-1}$ with $0.15 \mathrm{~mol} \cdot \mathrm{1}^{-1} \mathrm{NaCl}$.

Induction of diabetes. Following an overnight fast, pigs were administered $150 \mathrm{mg} \cdot \mathrm{kg}^{-1}$ streptozotocin (Sigma, Poole, UK) [42] in $50 \mathrm{ml}$ of $0.15 \mathrm{~mol} \cdot \mathrm{l}^{-1} \mathrm{NaCl}$ via the jugular vein catheter. Commencing the following morning and prior to feeding each morning and afternoon (see above) throughout the experiments a blood sample $(500 \mu \mathrm{l})$ was obtained from the arterial cannula and whole blood glucose concentration measured on a portable glucose meter (One Touch II; Lifescan, 
Abingdon, UK). The insulin dose was adjusted accordingly on the basis of these readings. Subcutaneous insulin treatment consisted of twice daily injections, given immediately before feeding, of a mixture of unmodified (Velosulin; Novo Nordisk, Crawley, UK) and NPH (Insulatard; Novo Nordisk) porcine insulins. A subcutaneous dose of between 4.8 and $7.2 \mathrm{nmol}$. $\mathrm{kg}^{-1}$ was typically required to maintain blood glucose within the required $5.0-10.0 \mathrm{mmol} \cdot \mathrm{l}^{-1}$ range.

Intravenous insulin treatments. Insulin was delivered to the jugular or portal vein from a mini-infusion pump (Disetronic Panomat V; Applied Medical Technology, Cambridge, UK) carried in a specially "in-house" designed harness worn on the animal's back. The pump delivered pre-programmed doses (5-20 $\mu \mathrm{l}$ in 3-min pulses) of unmodified porcine insulin (Velosulin) diluted in polygeline (Haemaccel; Hoechst, Hounslow, UK) containing $250 \cdot \mathrm{U} \mathrm{l}^{-1} \mathrm{ml}$ of heparin. The concentration of insulin delivered by the pump $\left(20.4-26.4 \mathrm{nmol} \cdot \mathrm{ml}^{-1}\right)$ and the flow rate settings employed $\left(100-400 \mu \mathrm{l} \cdot \mathrm{h}^{-1}\right)$ were individualy titrated in each animal based upon the prevailing blood glucose levels. A typical infusion profile consisted of insulin being delivered throughout the 24 -h period at a flow rate of $120 \mu \mathrm{l} \cdot \mathrm{h}^{-1}$ except for the $4 \mathrm{~h}$ immediately following the morning and afternoon meals when the infusion rate was increased by $233 \%$ above basal for the first $2 \mathrm{~h}$ and then by 192 and $25 \%$ above basal for the third and fourth hours after eating, respectively.

Insulin sensitivity and glucose turnover determinations. Measurements were made in each pig prior to diabetes induction and on day 28 of each infusion period, using the hyperinsulinaemic glucose clamp technique [43]. Through pre-conditioning, experiments could be performed on unstressed, fully conscious animals lying in purpose built holding crates.

Each pig was fasted for $17 \mathrm{~h}$ prior to the study which began at 08.30 hours, designated time 0 , with a primed $(<1.3 \mathrm{MBq}$, depending on basal glucose levels) [44] continuous infusion $\left(0.67 \mathrm{Mbq} \cdot \mathrm{min}^{-1}\right)$ of $\mathrm{D}\left(3-{ }^{3} \mathrm{H}\right)$-glucose $\left(514 \mathrm{Gbq} \cdot \mathrm{mmol}^{-1}\right.$; Amersham, Amersham, UK) in $0.15 \mathrm{~mol} \cdot \mathrm{l}^{-1} \cdot \mathrm{NaCl}$. To avoid an excessive rise in specific activity the initial continuous infusion rate of $8 \mathrm{ml} \cdot \mathrm{h}^{-1}$ was reduced, by $50 \%$ on each occasion, at 150,180 , and $210 \mathrm{~min}$ during the clamp. Blood samples $(500 \mu \mathrm{l})$ were taken at 5-min intervals from the arterial line throughout the study for the measurement of whole blood and plasma glucose concentrations using the glucose oxidase technique on a glucose analyser with an interassay coefficient of variation $(\mathrm{CV})$ of $3 \%$ (Yellow Springs Instruments, Yellow Springs, Ohio, USA). A 2-h equilibration period was employed and basal glucose turnover was measured over the ensuing $30 \mathrm{~min}$. Arterial blood samples $(5 \mathrm{ml})$ were taken at 0,120 , $130,135,140$ and $150 \mathrm{~min}$ for the measurement of insulin and intermediary metabolite concentrations and plasma glucose specific radioactivity. In the diabetic pigs the portable insulin infusion pump was then disconnected, and at $155 \mathrm{~min}$ in all animals an infusion via the jugular catheter of unmodified porcine insulin (Velosulin) diluted in Haemaccel was begun at a rate of $300 \mathrm{pmol} \cdot \mathrm{kg}^{-1} \cdot \mathrm{h}^{-1}$. Plasma blood glucose was then clamped at baseline levels by the variable infusion of $200 \mathrm{~g} \cdot \mathrm{l}^{-1}$ glucose containing $\left[3-{ }^{3} \mathrm{H}\right]$-glucose $\left(0.1 \mathrm{MBq} \cdot \mathrm{ml}^{-1}\right)$ [45]. After a $130-$ min equilibration period, stimulated glucose turnover and whole body insulin sensitivity were measured between 300 and $330 \mathrm{~min}$. Arterial blood samples $(5 \mathrm{ml})$ were therefore obtained at 300, 310, 320 and $330 \mathrm{~min}$ for the determination of insulin and metabolite concentrations and glucose specific radioactivity.

Intravenous glucose tolerance tests (IVGTTs) were performed before and after the studies (see above). After an overnight fast, $0.5 \mathrm{~kg}^{-1}$ of $500 \mathrm{~g} \cdot \mathrm{l}^{-1}$ glucose was administered via the jugular vein catheter over 1 min followed by a $30 \mathrm{ml}$ flush of $0.15 \mathrm{~mol} \cdot \mathrm{l}^{-1} \cdot \mathrm{NaCl}$. Arterial blood samples $(5 \mathrm{ml})$ were taken for glucose, insulin, and C-peptide measurement at 2-min intervals until $10 \mathrm{~min}$ and then at 5-min intervals until 60 min post-injection.

L ipid measurements. A $20 \mathrm{ml}$ fasting blood sample was obtained from each animal prior to diabetes induction and during the last week of peripheral and hepatic insulin delivery studies. Samples were allowed to clot and following centrifugation $\left(800 \times \mathrm{g}\right.$ for $15 \mathrm{~min}$ at $\left.4^{\circ} \mathrm{C}\right)$ serum was divided into 3 -ml aliquots and added to $50 \mathrm{ml}$ of a preservative "cocktail" consisting of $1.0 \mathrm{mmol} \cdot \mathrm{l}^{-1} \cdot \mathrm{Na}_{2}$-EDTA (BDH, Lutterworth, UK), $1.0 \mathrm{mmol} \cdot \mathrm{l}^{-1}$ phenylmethylsulfonylflouride $(\mathrm{BDH})$ in dimethylsulfoxide $(\mathrm{BDH})$, and $0.1 \mathrm{mmol} \cdot \mathrm{1}^{-1}$ butylated hydroxytoluene (Sigma) dissolved in absolute ethanol (BDH). Samples were stored at $4^{\circ} \mathrm{C}$ and were assayed less than $24 \mathrm{~h}$ after being obtained.

A nalytical procedures. Glucose specific activity was measured in plasma samples deproteinized with $\mathrm{Zn}_{2} \mathrm{SO}_{4}$ and $\mathrm{Ba}(\mathrm{OH})_{2}$ by the method of Somogyi [46]. The supernatant was freezedried (Edwards Modulyo; Edwards, Crawley, UK), redissolved in water and counted in Optiphase Hisafe II scintillant (LKB, Turko, Finland) on a liquid scintillation counter (Beckman).

Blood for lactate, alanine, pyruvate, glycerol and 3-hydroxybutyrate assays was collected into chilled perchloric acid $\left(0.77 \mathrm{~mol} \cdot \mathrm{l}^{-1}\right)$. Measurement was by fluorometric assay (interassay CV $6 \%$ ) adapted for centrifugal analysis [47]. The NEFA concentrations were colourimetrically determined using a commercially available kit (Wako Chemicals, Neuss, Germany) on a centrifugal analyser (interassay CV $3 \%$ ). Serum insulin was measured by double step [48] radioimmunoassay (RIA) (interassay CV 7.5\%). Porcine C-peptide was determined using an RIA kit employing a double antibody (interassay CV 6.1\%; Linco, St. Louis, Mo., USA). Serum fructosamine, an index of blood glucose control over the preceding 2 weeks [49] was measured colourimetrically using a diagnostic kit (interassay CV $1.5 \%$; Sigma).

Lipoprotein fractions were separated by sequential flotation ultracentrifugation [50] in a Beckman 70.1 Ti fixed angle rotor (Beckman, Palo Alto, Calif., USA) at $20^{\circ} \mathrm{C}$ and $100000 \times$ g. Separation of very low density lipoproteins (VLDL; $\mathrm{d}<1.006 \mathrm{~kg} \cdot \mathrm{l}^{-1}$ ), intermediate density lipoproteins (IDL; $1.006-1.019 \mathrm{~kg} \cdot \mathrm{l}^{-1}$ ), low density lipoproteins (LDL; $1.019-1.063 \mathrm{~kg} \cdot \mathrm{l}^{-1}$ ) and high density lipoproteins (HDL; $1.063-1.21 \mathrm{~kg} \cdot \mathrm{l}^{-1}$ ) was performed in 24-h steps as described previously [51, 52]. Total and free cholesterol, triglyceride and phospholipid in total serum and lipoprotein fractions were measured colourimetricaly using cholesterol CII, triglyceride $\mathrm{N}$ and phospholipid kits, respectively, from Wako on a Cobas Bio centrifugal analyser (Roche, Welwyn Garden City, $\mathrm{UK})$. In the serum and lipoprotein subfraction, the interassay CV was 2.2 and $3.2 \%$ for total cholesterol and triglyceride, respectively. The interassay $\mathrm{CV}$ for phospholipid ranged from $0.22 \%$ when measured in serum and the LDL fraction to $2.9 \%$ when measured in the HDL fraction. Free cholesterol interassay $\mathrm{CV}$ ranged from $0.70 \%$ when measured in serum and the LDL fraction to $7.2 \%$ when measured in the VLDL fraction. Protein concentration was measured by a modified Lowry technique [53] on a Cobas Bio centrifugal analyser. The interassay $\mathrm{CV}$ was $5.7 \%$.

Calculations. The metabolic clearance rate (MCR) of insulin $\left(\mathrm{ml} \cdot \mathrm{kg}^{-1} \cdot \mathrm{min}^{-1}\right)$ was calculated for the basal period of the clamp (0-150 min) from the ratio of the basal peripheral or 
Table 1. Body weight, pre- and postprandial whole blood glucose, $24 \mathrm{~h}$ insulin dose, serum fructosamine concentration and 30 -min post-IVGTT $(0.5 \mathrm{~g} / \mathrm{kg})$ serum C-peptide in six animals

\begin{tabular}{lcccc}
\hline & Baseline & Peripheral infusion & Portal infusion & $\begin{array}{c}\text { Infusion group mean } \\
\text { difference }\end{array}$ \\
\hline Body weight $(\mathrm{kg})$ & $34.8 \pm 1.6$ & $37.8 \pm 1.0$ & $37.4 \pm 0.9$ & $0.47 \pm 0.71$ \\
Stimulated C-peptide $\left(\mathrm{nmol}^{-1}\right)$ & $0.97 \pm 0.1$ & $0.04 \pm 0.004^{\mathrm{c}}$ & $0.04 \pm 0.008^{\mathrm{c}}$ & $-0.001 \pm 0.009$ \\
Blood glucose $\left(\mathrm{mmol} \cdot \mathrm{l}^{-1}\right)$ & & & & \\
$\quad$ Fasting & $3.1 \pm 0.1$ & $4.9 \pm 0.3^{\mathrm{a}}$ & $5.0 \pm 0.5^{\mathrm{a}}$ & $-0.22 \pm 0.42$ \\
$\quad$ Postprandial & $3.5 \pm 0.2$ & $6.4 \pm 0.4^{\mathrm{b}}$ & $6.0 \pm 0.8^{\mathrm{a}}$ & $0.35 \pm 0.92$ \\
Serum fructosamine $\left(\mathrm{mmol}^{\mathrm{b}} \cdot \mathrm{l}^{-1}\right)$ & $1.3 \pm 0.1$ & $2.1 \pm 0.1^{\mathrm{c}}$ & $2.0 \pm 0.1^{\mathrm{c}}$ & $0.03 \pm 0.09$ \\
Insulin dose $\left(\mathrm{nmol} \cdot \mathrm{kg}^{-1} \cdot \mathrm{day}^{-1}\right)$ & - & $2.4 \pm 0.1$ & $2.6 \pm 0.3$ & $-0.24 \pm 0.36$ \\
\hline
\end{tabular}

Mean \pm SEM

${ }^{\mathrm{a}} \mathrm{p}<0.05,{ }^{\mathrm{b}} \mathrm{p}<0.01,{ }^{\mathrm{c}} \mathrm{p}<0.001$ compared to baseline

portal insulin infusion rate and the corresponding mean arterial serum insulin level. Towards the end of the clamp period the MCR was similarly calculated except that the infusion rate of the peripherally administered insulin $\left(300 \mathrm{pmol} \cdot \mathrm{kg}^{-1}\right.$. $\left.\mathrm{h}^{-1}\right)$ was used. The rates of glucose appearance $\left(\mathrm{R}_{\mathrm{a}}\right)$ and glucose disappearance $\left(\mathrm{R}_{\mathrm{d}}\right)$ were isotopically determined during the basal (120-150 $\mathrm{min}$ ) and stimulated (300-330 min) periods of the clamp using the isotope-dilution equation $\mathrm{R}_{\mathrm{a}}=\mathrm{F} / \mathrm{SA}$; where $F$ is the infusion rate of tritiated glucose $\left(\mathrm{dpm} \mathrm{min}^{-1}\right.$ $\mathrm{kg}^{-1}$ ) and $\mathrm{SA}$ is the specific radioactivity of glucose $\left(\mathrm{dpm} \cdot \mathrm{mg}^{-1}\right)$. Hepatic glucose output (HGO) was taken to be equivalent to $R_{a}$ during the basal clamp period and was calculated for the insulin stimulated period of the clamp by subtraction of the glucose infusion rate from the $\mathrm{R}_{\mathrm{a}}$. The MCR of glucose $\left(\mathrm{ml} \cdot \mathrm{kg}^{-1} \cdot \mathrm{min}^{-1}\right)$ was calculated during the basal clamp period from the ratio of $\mathrm{R}_{\mathrm{d}}$ and the corresponding mean plasma glucose value and during the stimulated period by the ratio of mean glucose infusion rate and the corresponding mean plasma glucose value.

Statistical analysis. Unless otherwise stated, all results are presented as the mean \pm SEM for variables measured in six pigs. Differences between and within groups were assessed by Student's two-tailed paired t-test.

\section{Results}

Validity of model. Routine biochemical and haematological examinations performed on the pigs throughout the experimental period were consistent with the animals being in good health during the studies. The body weights of diabetic animals after 4 weeks of peripheral $(37.8 \pm 1.0 \mathrm{~kg})$ or portal $(37.4 \pm 0.9 \mathrm{~kg})$ insulin delivery were not significantly different and did not differ from those measured prior to streptozotocin administration $(34.8 \pm 1.6 \mathrm{~kg})$ (Table 1$)$.

Serum C-peptide levels were highest in control animals $\left(0.97 \pm 0.11 \mathrm{nmol} \cdot \mathrm{l}^{-1}\right) 15 \mathrm{~min}$ after glucose infusion, but were close to undetectable in diabetic animals $\left(0.04 \pm 0.00 \mathrm{nmol} \cdot 1^{-1}, \mathrm{p}<0.001\right)$ (Table 1$)$, and at all other times tested (results not shown). Preand postprandial blood glucose concentration was maintained within the $5.0-10.0 \mathrm{mmol} \cdot \mathrm{l}^{-1}$ target range from week 1 through to week 4 of each study. before induction of diabetes and during the last week of peripheral and portal insulin delivery 
Table 2. Serum insulin concentration and MCR, serum NEFA and triglyceride and whole-blood metabolite concentration at basal (0-150 $\mathrm{min})$ and insulin stimulated (300-330 min) steady states during the clamp in normal and diabetic pigs after receiving 4 weeks of insulin peripherally or hepatically

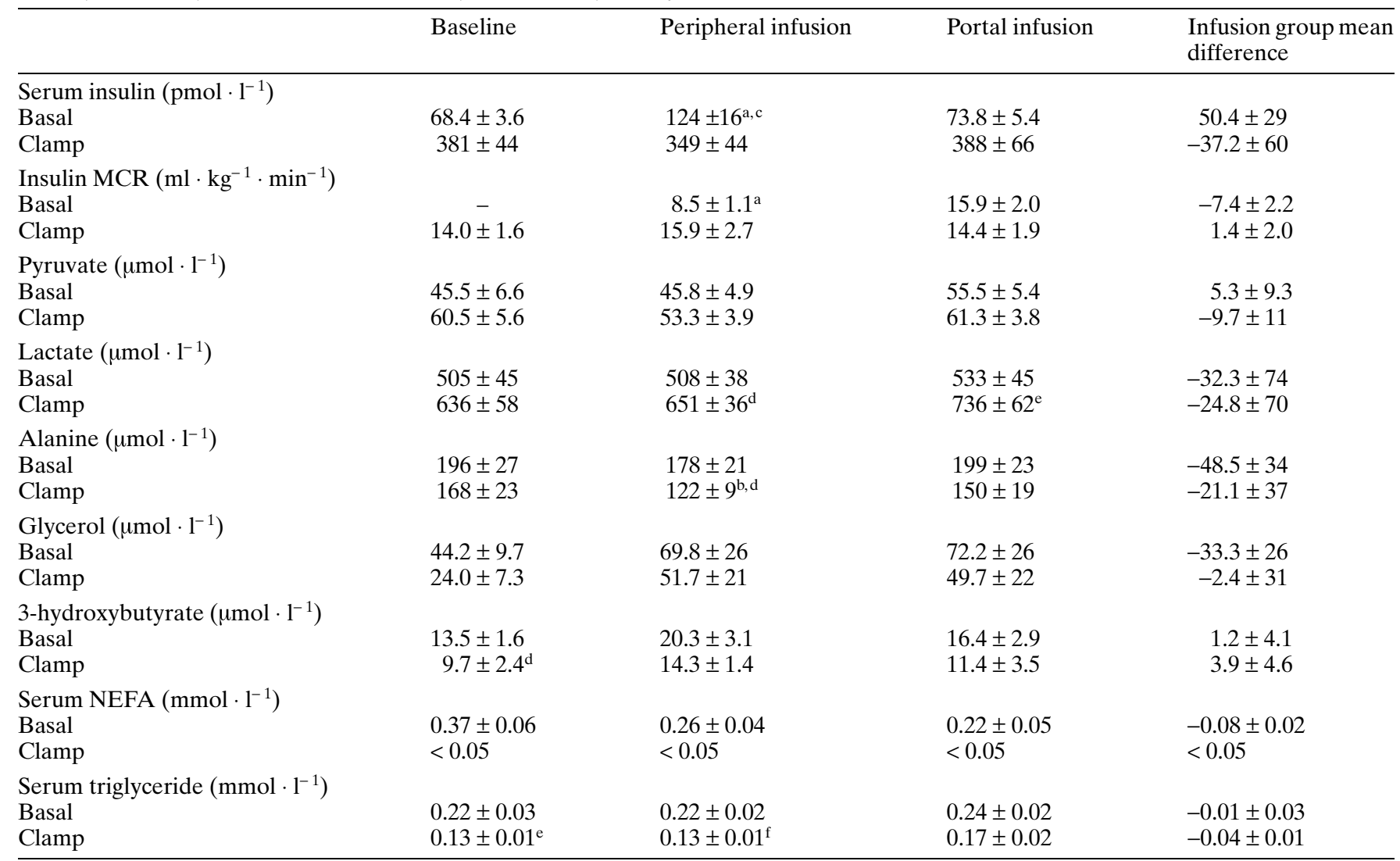

Mean \pm SEM

${ }^{\mathrm{a}} \mathrm{p}<0.05$ vs portal infusion; ${ }^{\mathrm{b}} p<0.05,{ }^{\mathrm{c}} p<0.01$ vs baseline; ${ }^{\mathrm{d}} \mathrm{p}<0.05,{ }^{\mathrm{e}} p<0.01,{ }^{\mathrm{f}} \mathrm{p}<0.001$ basal vs stimulated

periods of the clamp were comparable in the experimental groups, but approximately $3.0 \mathrm{mmol} \cdot \mathrm{l}^{-1}$ higher than in control animals (Table 3 ). The CV for plasma glucose over the time of measurement of glucose disposal during the clamps was $8.4 \pm 1.0 \%$. The plasma glucose specific radioactivity (SA) in each of the three study groups did not change significantly over the clamp period (Fig.1) mean basal SA being $886 \pm 72 \mathrm{dpm} \cdot \mathrm{mmol}^{-1}$ and $\mathrm{CV} 6.2 \pm 1.3 \%$, while clamp SA was $724 \pm 43 \mathrm{dpm} \cdot \mathrm{mmol} \cdot \mathrm{l}^{-1}$ with a CV of $5.4 \pm 0.8 \%$.

After 4 weeks of portally infused insulin, measured fasting HGO was not different from that determined in the pre-streptozotocin treated animals $\left(3.0 \pm 0.3\right.$ vs $\left.2.9 \pm 0.5 \mathrm{mg} \cdot \mathrm{kg}^{-1} \cdot \mathrm{min}^{-1}\right) \quad$ (Table 3$)$. The fasting HGO measured in the group previously peripherally infused was, however, more than $25 \%$ $(p<0.05)$ higher than that measured in the group previously portally infused or in normal control animals (Table 3). No significant difference existed between the three experimental groups in the basal MCR of glucose (Table 3). By the end of the clamp, HGO had fallen by a similar amount in the non-diabetic animals $\left(3.9 \pm 0.8 \mathrm{mg} \cdot \mathrm{kg}^{-1} \cdot \mathrm{min}^{-1}\right)$, the peripherally infused animals $\left(4.5 \pm 0.9 \mathrm{mg} \cdot \mathrm{kg}^{-1} \cdot \mathrm{min}^{-1}\right)$ and the portally infused animals $\left(3.9 \pm 0.5 \mathrm{mg} \cdot \mathrm{kg}^{-1} \cdot \mathrm{min}^{-1}\right)$. Suppressed HGO at the end of the clamp was not significantly different between the three groups (Table 3).

Glucose requirement over the last $30 \mathrm{~min}$ of the clamp was not different in the peripherally infused $\left(9.6 \pm 1.0 \mathrm{mg} \cdot \mathrm{kg}^{-1} \cdot \mathrm{min}^{-1}\right)$ and normal control animals $\left(8.1 \pm 0.3 \mathrm{mg} \cdot \mathrm{kg}^{-1} \cdot \mathrm{min}^{-1}\right)$. In the portally infused group the glucose requirement $(11.4 \pm 0.6 \mathrm{mg}$ $\left.\mathrm{kg}^{-1} \cdot \min ^{-1}\right)$ was higher $(\mathrm{p}<0.01)$ than in controls but not significantly different from that in the peripherally infused group (Table 3 ). Compared with prediabetic values glucose MCR were lower $(p<0.05)$ in the diabetic animals after 28 days of either peripheral $(-30 \%)$ or portal $(-23 \%)$ insulin delivery (Table 3$)$.

B lood intermediary metabolites. The steady-state fasting (0-150 $\mathrm{min})$ and end-of-clamp (300-330 $\mathrm{min}$ ) concentrations of whole-blood pyruvate, lactate, alanine, glycerol and 3-hydroxybutyrate and serum NEFAs and triglycerides are shown in Table 2. There were no significant differences in the fasting 
Table 3. Isoglycaemic hyperinsulinaemic clamp data in normal and diabetic pigs after 4 weeks of peripheral and hepatic insulin delivery

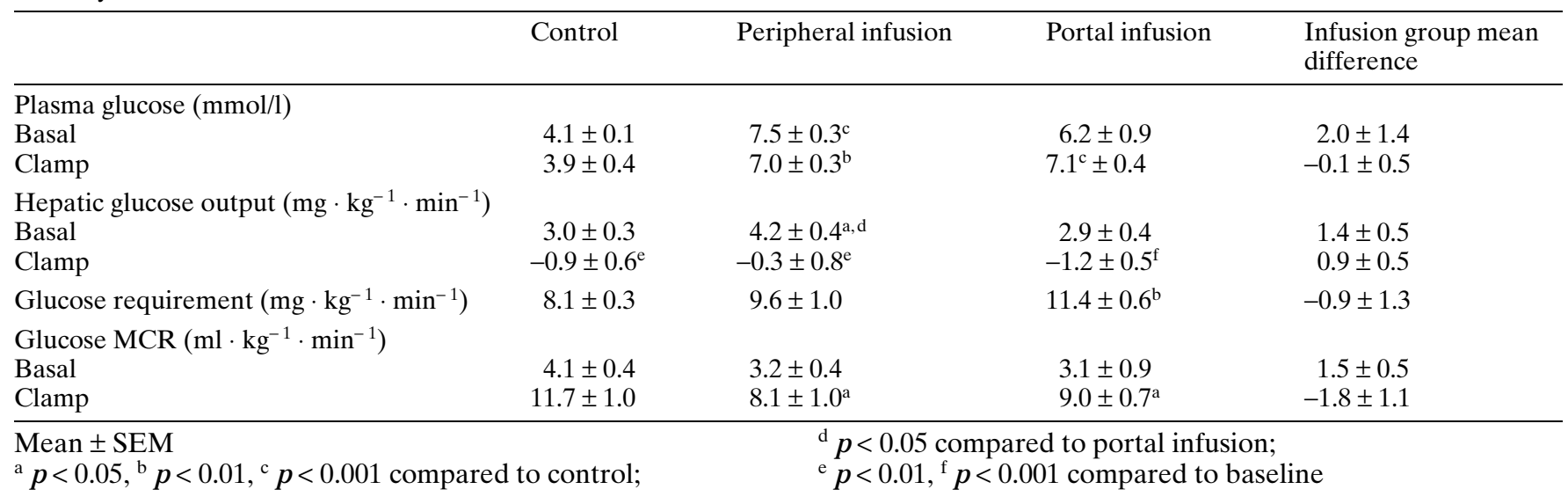

concentrations of these substrates between pre-streptozotocin treated animals and diabetic animals receiving insulin peripherally or portally (Table 2). Similarly, after 4 weeks of insulin infusion treatment, the route of insulin delivery did not appear to affect fasting intermediary metabolite concentrations (Table 2).

However, end of clamp alanine levels in the peripherally insulin-treated animals were significantly lower than those measured in animals before streptozotocin treatment $(p<0.05)$ (Table 2$)$. No other significant differences were found between the three study groups with respect to substrate levels during this period of hyperinsulinaemia (Table 2). In the normal control animals, pyruvate and lactate concentrations tended to increase during the clamp while those of alanine, glycerol, 3-hydroxybutyrate, triglyceride and NEFA tended to fall, but only for serum NEFA and triglyceride was this change statistically significant $(p<0.05$, Table 2$)$. Following peripheral insulin delivery whole blood lactate concentrations increased significantly during the clamp $(p<0.05)$, alanine, triglycerides and NEFA decreased $(p<0.05)$ and pyruvate, 3-hydroxybutyrate and glycerol remained unchanged (Table 2). After portal insulin infusion, lactate levels also increased during the clamps $(p<0.05)$, those of NEFA decreased $(p<0.05)$, while those of serum triglyceride and blood alanine, glycerol, pyruvate and 3-hydroxybutyrate were not detectably altered (Table 2 ).

Serum lipoproteins. The results obtained in the lipoprotein fractionation experiments along with the serum lipid levels for the non-diabetic and two diabetic study groups are shown in Table 4 . The total fasting serum cholesterol, triglyceride, free cholesterol and phospholipid concentrations in the two insulin treated groups were not significantly different from one another or from those in normal pigs (Table 4). Lipid levels in the lipoprotein subfractions were also not significantly different, but there was a consistent trend for total and free cholesterol, phospholipid and total protein in the LDL fraction to be higher after 4 weeks of peripherally infused insulin (Table 4). However, the total protein content of the HDL subfraction of these animals was significantly higher $(\mathrm{p}<0.05)$ than in animals receiving portally infused insulin $\left(96.1 \pm 3.5 \mathrm{vs} 86.3 \pm 3.2 \mathrm{mg} \cdot \mathrm{dl}^{-1}\right)(\mathrm{Ta}-$ ble 4).

\section{Discussion}

The pig by virtue of its considerable dietary, metabolic, endocrine and anatomical similarity to man is eminently suited as a model in which to examine the importance of the restoration of the portal-systemic insulin gradient for the continuance of normal intermediary and lipid metabolism and glucose turnover. The negative C-peptide response to glucose confirmed that the animals were rendered completely insulin deficient by streptozotocin and remained so throughout the experiments. Blood glucose control was equivalent in the groups of diabetic animals regardless of the route of insulin delivery. The similar serum fructosamine levels obtained would be equivalent (on the basis of a normal mean of $1.3 \mathrm{mmol} / \mathrm{l}$ ) to an $\mathrm{HbA}_{1 \mathrm{c}}$ of approximately $7.5 \%$ on the Diabetes Control and Complications trial (DCCT) assay [54].

Despite similar insulin requirements, the fasting insulin levels in the peripherally infused group were almost twice those of the controls or the portally infused animals. Hence basal insulin clearance rates in the portally infused animals were higher than in those peripherally infused. In contrast during the hyperinsulinaemic clamp period, when insulin was always peripherally infused, clearance rates were approximately the same in controls and in the two infusion groups. The lower rates calculated in the peripherally infused animals are consistent with the infused insulin escaping 'first-pass' hepatic degradation which 
Table 4. Serum and lipoprotein lipids in normal and diabetic pigs during the fourth week of peripheral or hepatic insulin delivery

\begin{tabular}{|c|c|c|c|c|c|}
\hline & & Lipoprotein & raction & & \\
\hline & & Total serum & VLDL & LDL & HDL \\
\hline Cholesterol $\left(\mathrm{mmol}^{-1}\right)$ & $\begin{array}{l}\text { Control } \\
\text { Peripheral infused } \\
\text { Portal infused } \\
\text { Infusion group mean difference }\end{array}$ & $\begin{array}{c}1.7 \pm 0.1 \\
1.9 \pm 0.1 \\
1.8 \pm 0.2 \\
0.08 \pm 0.15\end{array}$ & $\begin{array}{l}0.07 \pm 0.01 \\
0.09 \pm 0.01 \\
0.09 \pm 0.01 \\
\quad 0 \pm 0\end{array}$ & $\begin{array}{l}0.60 \pm 0.12 \\
0.82 \pm 0.08 \\
0.67 \pm 0.01 \\
0.15 \pm 0.08\end{array}$ & $\begin{array}{l}0.50 \pm 0.04 \\
0.57 \pm 0.04 \\
0.53 \pm 0.02 \\
0.03 \pm 0.05\end{array}$ \\
\hline Triglycerides $\left(\mathrm{mmol}^{-1}\right)$ & $\begin{array}{l}\text { Control } \\
\text { Peripheral infused } \\
\text { Portal infused } \\
\text { Infusion group mean difference }\end{array}$ & $\begin{array}{r}0.30 \pm 0.04 \\
0.32 \pm 0.06 \\
0.33 \pm 0.06 \\
-0.02 \pm 0.08\end{array}$ & $\begin{array}{l}0.13 \pm 0.03 \\
0.14 \pm 0.04 \\
0.13 \pm 0.04 \\
0.16 \pm 0.04\end{array}$ & $\begin{array}{l}<0.05 \\
<0.05 \\
<0.05 \\
\quad 0 \pm 0\end{array}$ & $\begin{array}{r}<0.05 \\
<0.05 \\
<0.05 \\
\quad 0 \pm 0\end{array}$ \\
\hline Free cholesterol $\left(\mathrm{mg} \cdot \mathrm{dl}^{-1}\right)$ & $\begin{array}{l}\text { Control } \\
\text { Peripheral infused } \\
\text { Portal infused } \\
\text { Infusion group mean difference }\end{array}$ & $\begin{array}{l}17.3 \pm 1.6 \\
17.7 \pm 1.2 \\
17.7 \pm 1.6 \\
0.03 \pm 1.9\end{array}$ & $\begin{array}{r}0.70 \pm 0.22 \\
0.39 \pm 0.16 \\
0.53 \pm 0.14 \\
-0.22 \pm 0.27\end{array}$ & $\begin{array}{l}8.4 \pm 0.15 \\
9.2 \pm 0.79 \\
8.3 \pm 1.0 \\
0.9 \pm 1.1\end{array}$ & $\begin{array}{l}6.5 \pm 0.70 \\
5.4 \pm 0.47 \\
4.9 \pm 0.48 \\
0.5 \pm 0.76\end{array}$ \\
\hline Phospholipid $\left(\mathrm{mg} \cdot \mathrm{dl}^{-1}\right)$ & $\begin{array}{l}\text { Control } \\
\text { Peripheral infused } \\
\text { Portal infused } \\
\text { Infusion group mean difference }\end{array}$ & $\begin{array}{r}74.1 \pm 5.0 \\
78.2 \pm 6.6 \\
73.2 \pm 6.4 \\
5.0 \pm 3.4\end{array}$ & $\begin{array}{r}1.7 \pm 0.39 \\
1.5 \pm 0.42 \\
1.7 \pm 0.40 \\
-0.13 \pm 0.63\end{array}$ & $\begin{array}{r}13.0 \pm 2.4 \\
17.6 \pm 2.0 \\
14.7 \pm 1.8 \\
2.8 \pm 2.0\end{array}$ & $\begin{array}{r}36.0 \pm 2.3 \\
37.5 \pm 4.4 \\
29.5 \pm 2.5 \\
8.0 \pm 5.0\end{array}$ \\
\hline
\end{tabular}

Mean \pm SEM

a $p<0.05$ compared with portal infusion

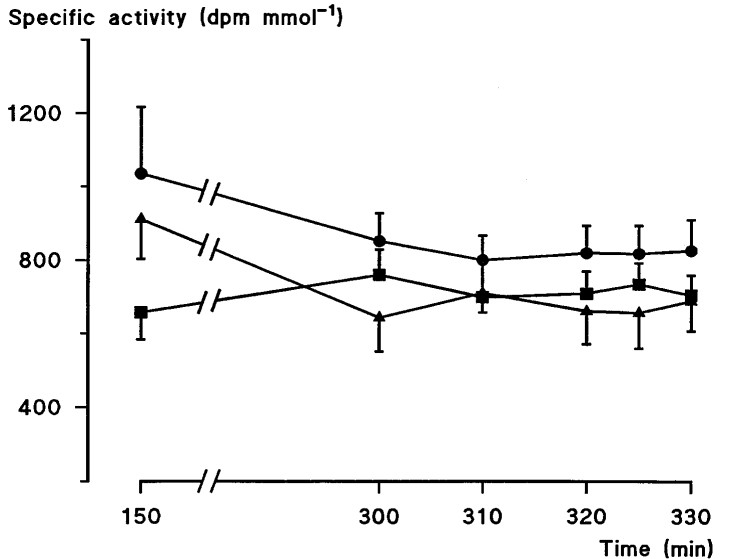

Fig. 1. ${ }^{3} \mathrm{H}$ Glucose specific radioactivity before $(150 \mathrm{~min})$ and during the insulin stimulated clamp period (300-330 min) in control animals $(\boldsymbol{\Delta})$ and in animals following 4 weeks of either peripheral ( $)$ or portal vein $(\bullet)$ insulin infusion. $p<0.05$ intravenous vs portal insulin infusion at $150 \mathrm{~min}$

can remove between 50 and $75 \%$ of insulin in the fasting state [55].

A lack of agreement exists among previous animal investigations, performed in rodents or dogs, concerning whether or not insulin delivery by the peripheral route results, as in our study, in raised $[3$, $7,9,13,17-21]$ or unchanged $[2,6,11,14-16]$ peripheral insulin levels. Studies in man comparing intraperitoneal and subcutaneous insulin delivery have similarly yielded conflicting results relating to the extent of systemic insulinisation [23-28, 56]. However, the systemic delivery of insulin which accompanies human pancreas transplantation has generally been found to lead to fasting peripheral hyperinsulinaemia [29-37].

Traditionally it has been assumed that hepatic glucose production is controlled by a direct effect of insulin on the liver and that adequate control using conventional therapy can only be achieved by raising peripheral insulin to supranormal concentrations. Despite peripheral hyperinsulinaemia in the peripherally infused group, however, in conjunction with equivalent blood glucose control, HGO remained considerably higher than in either the prediabetic animals or those on portal insulin delivery. Thus the levels of insulin achieved in the peripherally infused group may still not have been high enough to effectively control HGO. Indeed HGO was successfully switched-off when insulin levels were further raised during the clamps.

The importance of peripheral insulin concentrations in indirectly controlling $\mathrm{HGO}$ has steadily gained recognition $[1,5,57-60]$. In the present study fasting three-carbon substrate and NEFA concentrations were not dissimilar in the three groups. These results lend support to the concept that the long term control of HGO is not solely through a peripheral action of insulin on gluconeogenic substrate flux. It is possible nonetheless that the hyperinsulinaemia in the peripherally infused animals may have altered the activity and/or concentration of some other "peripheral messenger' thereby contributing to the increases in HGO observed. 
In the present study using the stimulated MCR of glucose as a measure of extrahepatic insulin responsiveness, it was found that neither route of insulin infusion was capable of restoring this variable to prediabetic values. However, by using a single relatively high dose of insulin in these clamp experiments without employing an additional low dose infusion, subtle differences between the two infusion groups in insulin sensitivity may have been missed. The lowered glucose clearance rate in both the portal and peripheral infusion groups is likely to be a result of the chronically raised glucose levels in both groups. This may involve defective GLUT 4 intrinsic activity and/ or translocation. Indeed abnormal transporter translocation has been previously documented in diabetic rats [61]. Had it been possible to employ a more sophisticated insulin infusion algorithm capable of normalising blood glucose concentrations it is likely that normal insulin sensitivity would have been restored. A recent study in rats found that islet grafts providing normal insulin supply to the portal vein restored insulin sensitivity to normal, something which was not observed in rat islet grafts with peripheral venous drainage [62].

Studies in humans which have examined the relative impact of subcutaneous compared to intraperitoneal insulin administration on lipid metabolism have generally [26, 63-65], although not always [24, 66], found the intraperitoneal administration to be superior in normalising lipid metabolism. The characteristic dyslipidaemia of IDDM patients involves hypertriglyceridaemia and lowered HDL cholesterol concentrations [67]. However, the only significant difference between the two diabetic groups observed in this study was in HDL protein levels. Raised HDL cholesterol levels have previously been recorded in intensively treated IDDM patients [68], but no differences in the Apo A-1 lipoprotein content which constitutes 70 to $80 \%$ of total HDL protein (the predominant pig HDL lipoprotein has a similar structure and function to human Apo A-1 [69] were observed in a subsequent study [70]. Serum LDL cholesterol content is generally normal in well controlled IDDM patients although increases have been observed in poorly controlled patients [67]. Hyperinsulinaemia is generally associated with increased LDL catabolism [71] although it is likely this effect could be modulated by nonenzymatic glycation of LDL. The mechanisms responsible for the apparent rise in LDL cholesterol, protein and phospholipid in the peripherally infused animals are currently under study.

In conclusion, the present study found that when compared in the same six pigs, peripheral and portal insulin delivery were equally effective in maintaining relative control of blood glucose, intermediary metabolite and lipid concentrations. However, this was accompanied by higher fasting insulin and HGO levels in the peripherally infused animals. Neither infusion route was capable of restoring normal rates of glucose clearance. The results therefore indicate that in this diabetic model the portal-peripheral insulin gradient is a prerequisite for the maintenance of both normal hepatic metabolism and peripheral insulin levels during the fasting period. Furthermore, even relatively mild hyperglycaemia has detrimental metabolic effects regardless of the route of insulin infusion.

A cknowledgements. This study was founded by a UK MRC Special project grant. The authors would like to thank Dr. Judith Webster for the lipid analyses.

\section{References}

1. Giacca A, Fisher SJ, Shi ZQ, Gupta R, Lickley HL, Vranic M (1992) Importance of peripheral insulin levels for insulin-induced suppression of glucose production in depancreatized dogs. J Clin Invest 90: 1769-1771

2. Fischer U, Rizza RA, Hall LD et al (1982) Comparison of peripheral and portal venous insulin administration on postprandial metabolic responses in alloxan-diabetic dogs. Effects of identical pre-programmed complex insulin infusion waveforms. Diabetes 31: 579-584

3. Goriya Y, Bahoric A, Marliss EB, Zinman B, Albisser AM (1981) The metabolic and hormonal responses to a mixed meal in unrestrained pancreatectomised dogs chronically treated by portal or peripheral insulin infusion. Diabetologia 21: 58-64

4. Ishida T, Chap Z, Chou J et al (1984) Effects of portal and peripheral venous insulin infusion on glucose production and utilization in depancreatized, conscious dogs. Diabetes 33: 984-990

5. Ader M, Bergman RN (1990) Peripheral effects of insulin dominate suppression of fasting hepatic glucose production. Am J Physiol 258: E1020-E1032

6. Botz CK, Leibel BS, Zingg W, Gander RE, Albisser AM (1976) Comparison of peripheral and portal routes of insulin infusion by a computer-controlled insulin infusion system (artificial endocrine pancreas). Diabetes 25: 691-700

7. Goriya Y, Bahoric A, Marliss EB, Zinman B, Albisser AM (1980) Blood glucose control and insulin clearance in unrestrained diabetic dogs portally infused with a portable insulin delivery system. Diabetologia 19: 452-457

8. Stevenson RW, Parsons JA, Alberti KG (1981) Comparison of the metabolic responses to portal and peripheral infusions of insulin in diabetic dogs. Metabolism 30: 745-752

9. Freyse EJ, Fischer U, Albrecht G, Marx S, Keilacker H (1987) The effect of prehepatic insulin administration on alanine flux rates in diabetic dogs. Diabetologia 30: 402-408

10. Stevenson RW, Parsons JA, Alberti KG (1983) Effect of intraportal and peripheral insulin on glucose turnover and recycling in diabetic dogs. Am J Physiol 244: E190-E195

11. Rizza RA, Westland RE, Hall LD et al (1981) Effect of peripheral versus portal venous administration of insulin on postprandial hyperglycemia and glucose turnover in alloxan diabetic dogs. Mayo Clin Proc 56: 434-438

12. Madison LL, Unger RH (1958) The physiological significance of the secretion of endogenous insulin into the portal circulation. 1. Comparison of effects of glucagon-free insulin administered via the portal vein and via a peripheral vein on the magnitude of hypoglycaemia and peripheral glucose utilization. J Clin Invest 37: 631-639 
13. Brown J, Mullen Y, Clark WR, Molnar IG, Heininger D (1979) Importance of hepatic portal circulation for insulin action in streptozotocin-diabetic rats transplanted with fetal pancreases. J Clin Invest 64: 1688-1694

14. Kruszynska YT, Home PD, Alberti KG (1985) Comparison of portal and peripheral insulin delivery on carbohydrate metabolism in streptozotocin-diabetic rats. Diabetologia 28: 167-171

15. Albisser AM, Nomura M, Greenberg GR, McPhedran NT (1986) Metabolic control in diabetic dogs treated with pancreatic autotransplants and insulin pumps. Diabetes 35: 97100

16. Falholt K, Cutfield R, Alejandro R, Volund A, Heding LG, Mintz DH (1991) Influence of portal delivery of insulin on intracellular glucose and lipid metabolism. Metabolism 40: 122-126

17. Homan M, Nicholson CP, Katz H et al (1991) Effects of chronic systemic insulin delivery on insulin action in dogs. Diabetologia 34: 702-708

18. Barron P, Humar A, Davies J, Radziuk J (1994) Insulin sensitivity and glucose tolerance following transposition of pancreatic venous drainage to the systemic circulation. Transplant Proc 26: 487-489

19. Kryshak EJ, Butler PC, Marsh C et al (1990) Pattern of postprandial carbohydrate metabolism and effects of portal and peripheral insulin delivery. Diabetes 39: 142-148

20. Radziuk J, Barron P, Najm H, Davies J (1993) The effect of systemic venous drainage of the pancreas on insulin sensitivity in dogs. J Clin Invest 92: 1713-1721

21. Shokouh-Amiri MH, Falholt K, Holst JJ, Rahimi-Saber S, Orbaek Andersen H, Jensen SL (1992) Pancreas endocrine function in pigs after segmental pancreas autotransplantation with either systemic or portal venous drainage. Transplant Proc 24: 799-800

22. Nelson JA, Stephen R, Landau ST, Wilson DE, Tyler FH (1982) Intraperitoneal insulin administration produces a positive portal-systemic blood insulin gradient in unanesthetized unrestrained swine. Metabolism 31: 969-972

23. Robert JJ, Chauvet D, Darmaun D, Leblanc H (1993) Hepatic glucose production during intraperitoneal and intravenous closed-loop insulin regulation of blood glucose in type 1 (insulin-dependent) diabetic patients. Diabetologia 36: $1185-1190$

24. Lahtela JT, Mustonen J, Pasternack A (1995) Comparison of intraperitoneal and subcutaneous insulin administration on insulin sensitivity and serum lipids in type I diabetic patients on continuous ambulatory peritoneal dialysis treatment. Clin Sci 88: 427-432

25. Selam J-L, Raccah D, Jean-Didier N, Lozano JL, Waxman K, Charles MA (1992) Randomized comparison of metabolic control achieved by intraperitoneal insulin infusion with implantable pumps versus intensive subcutaneous insulin therapy in type I diabetic patients. Diabetes Care 15: 53-58

26. Selam J-L, Kashyap M, Alberti KG et al (1989) Comparison of intraperitoneal and subcutaneous insulin administration on lipids, apolipoproteins, fuel metabolites, and hormones in type I diabetes mellitus. Metabolism 38: 908-912

27. Bouhanick B, M'Bemba J, Robert J-J, Rongier M, Slama G, Selam J-L (1994) Effects of peritoneal vs peripheral venous insulin delivery on glucose production and utilization in type 1 diabetic patients. Diab Nutr Metab 7: 213217

28. Monti LD, Piatti PM, Home PD, Tomson C, Alberti KGMM (1992) The effect of intraperitoneal insulin delivery on carbohydrate metabolism in type 1 (insulin-dependent) diabetic patients. Diabetes Res Clin Prac 15: 237-244
29. Elahi D, Clark BA, McAloon-Dyke M et al (1991) Islet cell responses to glucose in human transplanted pancreas. Am J Physiol 261: E800-E808

30. Osei K, Cottrell DA, Henry ML, Tesi RJ, Ferguson RM, O'Dorisio TM (1992) Insulin insensitivity and glucose effectiveness in type I diabetic allograft pancreas recipients. Transplant Proc 24: 828-830

31. Katz H, Homan M, Velosa J, Robertson P, Rizza R (1991) Effects of pancreas transplantation on postprandial glucose metabolism. N Engl J Med 325: 1278-1283

32. Luzi L, Secchi A, Facchini F et al (1990) Reduction of insulin resistance by combined kidney-pancreas transplantation in type 1 (insulin-dependent) diabetic patients. Diabetologia 33: 549-556

33. Wilczek H, Gunnarsson R, Felig P, Ostman J, Groth CG, Wahren J (1991) Normalization of hepatic glucose regulation despite systemic insulin delivery. Studies in patients with pancreatic transplantation for type 1 (insulin-dependent) diabetes mellitus. Diabetologia 34: 345-349

34. Christiansen E, Andersen HB, Rasmussen K et al (1993) Pancreatic beta-cell function and glucose metabolism in human segmental pancreas and kidney transplantation. Am J Physiol 264: E441-E449

35. Diem P, Abid M, Redmon JB, Sutherland DE, Robertson RP (1990) Systemic venous drainage of pancreas allografts as independent cause of hyperinsulinemia in type I diabetic recipients. Diabetes 39: 534-540

36. Boden G, Chen X, Ruiz J, Heifets M, Morris M, Badosa F (1994) Insulin receptor downregulation and impaired antilipolytic action of insulin in diabetic patients after pancreas/kidney transplantation. J Clin Endocrinol Metab 78: 657-663

37. Rooney DP, Robertson RP (1996) Hepatic insulin resistance after pancreas transplantation in type I diabetes. Diabetes 45: $134-138$

38. Krusch DA, Brown KB, Cornett G, Freedlender AE, Kaiser DL, Hanks JB (1989) Insulin-dependent and insulin-independent effects after surgical alterations of the pancreas. Surgery 106: 60-68

39. Marchesini G, Zoli M, Dondi C et al (1982) Blood glucose and glucoregulatory hormones in liver cirrhosis: a study of 24 hour profiles and the role of portal-systemic shunting. Gastroenterol Clin Biol 6: 272-278

40. Kruszynska YT, Home PD, McIntyre N (1991) Relationship between insulin sensitivity, insulin secretion and glucose tolerance in cirrhosis. Hepatology 14: 103-111

41. Rerat A, Chayvialle JA, Kande J, Vaissade P, Vaugelade P, Bourrier T (1985) Metabolic and hormonal effects of test meals with various protein contents in pigs. Can J Physiol Pharmacol 63: 1547-1559

42. Wilson JD, Dhall DP, Simeonovic CJ, Lafferty KJ (1986) Induction and management of diabetes mellitus in the pig. Aust J Exp Biol Med Sci 64: 489-500

43. DeFronzo RA, Tobin JD, Andres R (1979) Glucose clamp technique: a method for quantifying insulin secretion and resistance. Am J Physiol 237: E214-E223

44. Hother-Nielsen O, Beck-Nielsen H (1990) On the determination of basal glucose production rate in patients with type 2 (non-insulin-dependent) diabetes mellitus using primed continuous $3-{ }^{3} \mathrm{H}$-glucose infusion. Diabetologia 33: 603-610

45. Finegood DT, Bergman RN, Vranic M (1987) Estimation of endogenous glucose production during hyperinsulinemiceuglycemic glucose clamps. Comparison of unlabeled and labeled exogenous glucose infusates. Diabetes 36: 914-924

46. Somogyi M (1945) Determination of blood sugar. J Biol Chem 160: 69-73 
47. Harrison J, Hodson AW, Skillen AW, Stappenbeck R, Agius L, Alberti KG (1988) Blood glucose, lactate, pyruvate, glycerol, 3-hydroxybutyrate and acetoacetate measurements in man using a centrifugal analyser with a fluorimetric attachment. J Clin Chem Clin Biochem 26: 141-146

48. Soeldner JS, Slone D (1965) Critical variable in the radioimmunoassay of serum insulin using the double antibody technique. Diabetes 14: 771-779

49. Baker JR, O'Connor JP, Metcalf PA, Lawson MR, Johnson RN (1983) Clinical usefulness of estimation of serum fructosamine concentration as a screening test for diabetes mellitus. BMJ Clin Res 287: 863-867

50. Havel RJ, Eder HA, Bragdon JH (1955) The distribution and chemical composition of ultracentrifugally separated lipoproteins in human serum. J Clin Invest 34: 1345-1353

51. Mahley RW, Weisgraber KH, Innerarity T, Brewer HB Jr. Assmann G (1975) Swine lipoproteins and atherosclerosis. Changes in the plasma lipoproteins and apoproteins induced by cholesterol feeding. Biochemistry 14: 2817-2823

52. Stewart MW, Laker MF, Dyer RG et al (1993) Lipoprotein compositional abnormalities and insulin resistance in type II diabetic patients with mild hyperlipidemia. Arterioscler Thromb 13: 1046-1052

53. Markwell MA, Haas SM, Bieber LL, Tolbert NE (1978) A modification of the Lowry procedure to simplify protein determination in membrane and lipoprotein samples. Anal Biochem 87: 206-210

54. The DCCT Research Group (1993) The diabetes control and complications trial (DCCT): The effect of intensive diabetes treatment on long-term complications in IDDM. N Engl J Med 329: 977-986

55. Horwitz DL, Starr JI, Mako ME, Blackward WG, Rubenstein AH (1975) Proinsulin, insulin, and C-peptide concentrations in human portal and peripheral blood. J Clin Invest 55: $1278-1283$

56. Shishko PI, Kovalev PA, Goncharov VG, Zajarny IU (1992) Comparison of peripheral and portal (via the umbilical vein) routes of insulin infusion in IDDM patients. Diabetes 41: 1042-1049

57. Prager R, Wallace P, Olefsky JM (1987) Direct and indirect effects of insulin to inhibit hepatic glucose output in obese subjects. Diabetes 36: 607-611

58. Poulin RA, Steil GM, Moore DM, Ader M, Bergman RN (1994) Dynamics of glucose production and uptake are more closely related to insulin in hindlimb lymph than in thoracic duct lymph. Diabetes 43: 180-190

59. Lewis GF, Zinman B, Groenewoud Y, Vranic M, Giacca A (1996) Hepatic glucose production is regulated both by direct hepatic and extrahepatic effects of insulin in humans. Diabetes 45: 454-462

60. Sindelar DK, Balcom JH, Chu CA, Neal DW, Cherrington AD (1996) A comparison of the effects of selective increases in peripheral or portal insulin on hepatic glucose production in the conscious dog. Diabetes 45: 1594-1604

61. Klip A, Ramlal T, Bilan PJ, Cartee GD, Gulve EA, Holloszy JO (1990) Recruitment of GLUT-4 glucose transporters by insulin in diabetic rat skeletal muscle. Biochem Biophys Res Commun 172: 728-736

62. Guan J, Zucker PF, Behme MT, Zong R, Atikson P, Dupre J (1997) Insulin resistance is prevented by portal delivery of insulin in rats with renal subcapsular islet grafts. Diabetes 46: 372-378

63. Ruotolo G, Parlavecchia M, Taskinen MR et al (1994) Normalization of lipoprotein composition by intraperitoneal insulin in IDDM. Role of increased hepatic lipase activity. Diabetes Care 17: 6-12

64. Hughes TA, Gaber OA, Amiri HS et al (1994) Lipoprotein composition in insulin dependent diabetes mellitus with chronic renal failure: Effect of kidney and pancreas transplantation. Metabolism 43: 333-347

65. Bagdade JD, Dunn FL, Eckel RH, Ritter MC (1994) Intraperitoneal insulin therapy corrects abnormalities in cholesteryl ester transfer and lipoprotein lipase activities in insulin-dependent diabetes mellitus. Arterioscler Thromb 14: 1933-1939

66. Bauersachs R, Piwernetz K, Renner R et al (1993) Hormone and substrate levels after long-term continuous intraperitoneal insulin infusion in insulin-dependent mellitus. Diab Nutr Metab 6: 25-32

67. Brown WV (1994) Lipoprotein disorders in diabetes mellitus. Med Clin North Am 78: 143-161

68. Dunn FL, Pielri A, Raskin P (1981) Plasma lipid and lipoprotein levels with continuous subcutaneous insulin infusion in type I diabetes mellitus. Ann Intern Med 95: 426431

69. Knipping GM, Kostner GM, Holasek A (1975) Studies on the composition of pig serum lipoproteins. Isolation and characterization of different apoproteins. Biochim Biophys Acta 393: 88-99

70. Taskinen MR, Kahri J, Koivisto V, Shepherd J, Packard CJ (1992) Metabolism of HDL apolipoprotein A-I and A-II in type 1 (insulin-dependent) diabetes mellitus. Diabetologia 35: 347-356

71. Mazzone T, Foster D, Chait A (1984) In vivo stimulation of low-density lipoprotein degradation by insulin. Diabetes 33: 333-338 